\title{
Central corneal thickness in black Cameroonian ocular hypertensive and glaucomatous subjects
}

This article was published in the following Dove Press journal:

Clinical Ophthalmology

22 November 2010

Number of times this article has been viewed

\section{Christelle Domngang}

Noche'

André Omgbwa Eballe ${ }^{2}$

Assumpta Lucienne Bella ${ }^{3}$

'Innel Medical Center, ${ }^{2}$ Faculty of Medicine, University of Douala,

${ }^{3}$ Faculty of Medicine and Biomedical Sciences, University of Yaoundé, Cameroon
Correspondence: Christelle Domngang Noche

Centre medical Innel, PO Box 12 7I5

Yaoundé, Cameroon

Tel (237) 99936709

Fax (237) 22217897

Email cabinet_innel@yahoo.fr
Purpose: To evaluate central corneal thickness (CCT) in a black Cameroonian population of ocular hypertensive and glaucomatous subjects.

Material and methods: This was a prospective study undertaken with an ultrasonic pachymeter from January 2009 to December 2009 in an eye clinic (INNEL Medical center) in Yaoundé, Cameroon.

Results: One hundred subjects (200 eyes) were enrolled in the study. Sixty subjects were glaucomatous (primary open angle glaucoma, POAG group), and 40 ocular hypertensive (OHT group). The mean age of the sample was 52.60 \pm 12.23 years. For the whole sample, CCT was $534.71 \pm 37.95 \mu \mathrm{m}$ in the right eye and $533.61 \pm 37.67 \mu \mathrm{m}$ in the left eye, with no statistically significant difference between the 2 eyes $(P=0.446)$. CCT in the POAG group was $526.30 \pm 37.34 \mu \mathrm{m}$ in the right eye and $524.90 \pm 35.92 \mu \mathrm{m}$ in the left eye. CCT in the OHT group was $547.32 \pm 35.71 \mu \mathrm{m}$ in the right eye and $546.67 \pm 36.85 \mu \mathrm{m}$ in the left eye. There was a statistically significant difference between CCT of the 2 groups (right eye: $P=0.013$; left eye: $P=0.007)$.

Conclusion: Mean CCT of ocular hypertensive subjects was thicker than CCT of glaucomatous ones in our Cameroonian sample. However, in both ocular hypertensive or glaucomatous patients, CCT of black Cameroonians is thinner than that reported in other studies in Caucasian populations.

Keywords: central corneal thickness, ocular hypertension, glaucoma, black Cameroonian

\section{Introduction}

Glaucomatous neuropathy, characterized by progressive loss of retinal ganglion cells and their axons, ${ }^{1}$ is manifested by a pathological optic disc and visual field damage. Ocular hypertension (OHT) is one of the risk factors. Following numerous studies in Western countries that have demonstrated the value of the measurement of central corneal thickness (CCT), it has become a routine examination as well as a measure of intraocular pressure (IOP) ${ }^{2-11}$ before OHT is proven. However, it is not performed routinely in the eye care centers in Cameroon. CCT has an impact on IOP, which is the only directly modifiable risk factor and is recognized as being a factor in progression to glaucoma in patients with OHT (factor 1-18 depending on the CCT) ${ }^{2,3}$ Inter-racial $^{12-17}$ and intra-racial ${ }^{2,6,18-21}$ differences in CCT have highlighted the thinner corneas of black people compared with other races. However, most of these studies in black populations were based on the analysis of African Americans or African Caribbeans. Studies of CCT in black Africans have been few. ${ }^{18-20}$ 
The purpose of this study was to evaluate CCT in a black Cameroonian population with isolated OHT or primary open angle glaucoma (POAG).

\section{Materials and methods}

This was a prospective study in a center for eye care (Medical Center Innel) in Yaoundé, Cameroon which was performed from January 1 to December 31, 2009. Verbal informed consent was obtained from all subjects who participated in this study.

\section{Inclusion criterion}

Subjects had to present an IOP higher than $21 \mathrm{mmHg}$ before any treatment. This criterion was based on the average of 3 IOP measurements performed in the morning with a calibrated Goldmann applanation tonometer.

\section{Exclusion criteria}

Any person having a corneal disease or having undergone corneal eye surgery was excluded from the study. Subjects with a refractive error higher than 8 diopters for myopia, 4 diopters for hypermetropia and 3 diopters for astigmatism to avoid any interference on the measurement of IOP or CCT were excluded. Subjects with OHT and with an unreliable visual field (more than $30 \%$ loss of fixation, more than $20 \%$ of false positives or false negatives) were not enrolled.

\section{Procedure}

All subjects with OHT received a comprehensive eye exam. This review consisted of an evaluation of the corrected far visual acuity on the Snellen chart, a biomicroscopic examination of the anterior segment with a Haag-Streit slit lamp model, a measurement of IOP with a Goldmann applanation tonometer (mean of 3 measurements), a record of 3 visual fields with the automatic perimeter Haag-Streit model Octopus 301 white-white, a static gonioscopic examination with a Goldmann 3-mirror lens, and an examination of the fundus with a 78 diopter Volk lens after pupil dilation with tropicamide which evaluated the optic nerve head and the peripapillary area. A color photograph of the optic disc was taken with a Topcon fundus camera. CCT was measured (average of 5 measurements [SD $<5 \mu \mathrm{m}$ ]) by means of a hand-held ultrasound pachymeter (Quantel Medical Inc, Pocket II model, Clermont-Ferrand, France). CCT was measured in the morning between 0900 and $1200 \mathrm{~h}$ before taking the IOP and after instillation of $1 \mathrm{drop}$ of $0.4 \%$ oxybuprocaine hydrochloride. The pachymeter probe was placed perpendicular to the center of the cornea.
All ophthalmologic examinations were performed by the same physician.

\section{Group definitions}

Diagnosis of POAG was made on the basis of 3 visual field glaucomatous abnormalities, an examination of an open irido-corneal angle of $360^{\circ}$ and structural damage of the optic nerve head (cup/disc ratio greater than 0.4 ). Diagnosis of OHT was made on the basis of the absence of functional impairment in visual fields (Octopus white-white) and a normal optic cup (cup/disc ratio less than 0.4 ). Thus, on the basis of these criteria, 2 groups were formed: the ocular hypertensive subjects (OHT group) and the primary open angle glaucomatous subjects (POAG group).

\section{Statistical analysis}

Statistical analysis was carried out for age, sex and CCT using Epi Info 3.5.1, Open Epi Version 2.3 and, SPSS version 10. Student's $t$ test was used to compare the mean values of CCT according to gender and OHT versus glaucoma. The comparison of CCT between the right and the left eye was also done with the Student's $t$ test (paired samples). Moreover, Student's $t$ test (independent samples) was used to compare the mean values of CCT from our study with a reference one. The test for the analysis of variance (ANOVA) was used to compare the means values of CCT according to age. The linear regression was used for the multivariate model. The significance of statistical tests was set at $P<0.05$.

\section{Results}

\section{Population characteristics}

One hundred subjects (200 eyes) meeting the inclusion criteria were studied. The study population consisted of 53 (53\%) males and 47 (47\%) women. The POAG group consisted of 60 subjects, 31 men and 29 women, and the OHT group consisted of 40 subjects, 22 men and 18 women. Average age of the study population was $52.60 \pm 12.23$ years (min-max: 11-77 years). The age group most represented was that of 51 to 60 years, making up $38 \%$ of subjects $(n=38)$. Average age for men was $51.20 \pm 12.52$ years (range: $11-74$ years) and for women $54.17 \pm 11.84$ years (range: $29-77$ years). The mean ages of men and women did not differ significantly $(P>0.05, t$ test). Average age in the POAG group was $55.93 \pm 12.47$ years (range: $11-77$ years) and in the OHT group $47.60 \pm 10.09$ years (range: $23-65$ years). The OHT group subjects were significantly younger than the POAG group ones $(P=0.0003, t$ test, Table 1$)$. 
Table I Characteristics of the population

\begin{tabular}{lllll}
\hline & Number & Mean age \pm SD & Min-Max & $P$ \\
\hline Sex & & & & \\
$\quad$ Males & 53 & $51.20 \pm 12.52$ & $11-74$ & 0.3507 \\
$\quad$ Females & 47 & $54.17 \pm 11.84$ & $29-77$ & \\
Groups & & & & \\
$\quad$ POAG & 60 & $55.93 \pm 12.47$ & $11-77$ & 0.0003 \\
OHT & 40 & $47.60 \pm 10.09$ & $23-65$ & \\
\hline
\end{tabular}

Abbreviations: $\mathrm{OHT}$, ocular hypertension; POAG, primary open angle glaucoma.

\section{Central corneal thickness}

\section{According to eye}

Average CCT was 534.71 $\pm 37.95 \mu \mathrm{m}$ (min-max: 445-639) in the right eye and $533.61 \pm 37.67 \mu \mathrm{m}$ (min-max: 444-649) in the left eye. The difference between the right and left eyes was not statistically significant $(P>0.05$, paired samples $t$ test). Average CCT of both eyes was $534.15 \pm 37.7 \mu \mathrm{m}$.

\section{According to gender}

Men $(\mathrm{n}=53)$ had an average CCT of $543.01 \pm 39.03 \mu \mathrm{m}$ (min-max: 455-639) in the right eye and $542.37 \pm 39.71 \mu \mathrm{m}$ (min-max: 462-649) in the left eye. Women $(\mathrm{n}=47)$ had an average CCT of $525.34 \pm 34.77 \mu \mathrm{m}$ (min-max: 445-593) in the right eye and $523.72 \pm 32.90 \mu \mathrm{m}$ (min-max: 444-588) in the left eye. The cornea of the men was significantly thicker than that of the women (right: $P=0.027$ and left $P=0.017$, $t$ test, Table 2).

\section{According to group}

Average CCT of the POAG group $(\mathrm{n}=60)$ was $526.30 \pm 37.34 \mu \mathrm{m}(\min -\max : 445-615)$ in the right eye and $524.90 \pm 35.92 \mu \mathrm{m}$ (min-max: 444-604) in the left eye. In the OHT group $(\mathrm{n}=40)$, average CCT was $547.32 \pm 35.71 \mu \mathrm{m}$ (min-max: 463-639) in the right eye and $546.67 \pm 36.85 \mu \mathrm{m}$ (min-max: 471-649) in the left eye. Average CCT in the OHT group was significantly

Table 2 Central corneal thickness (CCT) according to gender

\begin{tabular}{|c|c|c|c|c|}
\hline & Right CCT & & Left CCT & \\
\hline & $\begin{array}{l}\text { Mean } \pm \text { SD }(\mu \mathrm{m}) \\
\min -\max (95 \% \mathrm{Cl})\end{array}$ & $\mathbf{n}$ & $\begin{array}{l}\text { Mean } \pm \text { SD }(\mu \mathrm{m}) \\
\min -\max (95 \% \mathrm{Cl})\end{array}$ & $\mathbf{n}$ \\
\hline Male & $\begin{array}{l}543.01 \pm 39.03 \\
455 ; 639 \\
(532.50-553.49)\end{array}$ & 53 & $\begin{array}{l}542.37 \pm 39.71 \\
462-649 \\
(531.6 I-552.98)\end{array}$ & 53 \\
\hline Female & $\begin{array}{l}525.34 \pm 34.77 \\
445-593 \\
(515.38-535.22)\end{array}$ & 47 & $\begin{array}{l}523.72 \pm 32.90 \\
444-588 \\
(514.29-553.10)\end{array}$ & 47 \\
\hline$P$ & 0.0276 & & 0.0170 & \\
\hline
\end{tabular}

greater than that of the POAG group (right: $P=0.013$ and left $P=0.007, t$ test, Table 3 ). The linear regression shows that this difference of CCT between the 2 groups was not correlated with age or gender (Table 4). Moreover, within each group (OHT and POAG), age had no significant effect on CCT (Table 5, Figure 1).

\section{Discussion}

\section{Age and gender}

In the study population, OHT group subjects were significantly younger than POAG group subjects. The age difference between the 2 groups can be explained by the increased incidence of glaucoma with age regardless of race. ${ }^{5,22-24}$ The average age of subjects in the POAG group was higher than that found by Fanny et al ${ }^{18}(44.4 \pm 12.7$ years, $\mathrm{n}=170)$ in a black population (Ivorian). However, it is close to the average age of the population studied by Mercieca et a ${ }^{15}$ (61.9 \pm 9.1 years, $n=36)$, also in a study on black African subjects, and below the average age reported by Bron et $\mathrm{al}^{2}$ and La Rosa et $\mathrm{al}^{12}$ in Caucasian populations (minimum of mean ages reported: 67 years). This can be explained by the precocity of POAG in black subjects highlighted in various comparative studies. ${ }^{4,5}$

\section{Central corneal thickness}

\section{According to eye}

In our study, average CCT of the cornea of the right and left eyes didn't present a statistically significant difference. Our results are concordant with those of Bron et al, ${ }^{2}$ La Rosa et al, ${ }^{12}$ and Fanny et al, ${ }^{18}$ which also noted the absence of a statistically significant difference between the right and the left eyes.

\section{According to gender}

Average CCT was significantly thicker in men than women despite no statistically significant difference in their

Table 3 Central corneal thickness (CCT) according to group (POAG and OHT)

\begin{tabular}{|c|c|c|c|c|}
\hline & Right CCT & & Left CCT & \\
\hline & $\begin{array}{l}\text { Mean } \pm S D(\mu \mathrm{m}) \\
\min -\max (95 \% \mathrm{Cl})\end{array}$ & $\mathbf{n}$ & $\begin{array}{l}\text { Mean } \pm \text { SD }(\mu \mathrm{m}) \\
\min -\max (95 \% \mathrm{Cl})\end{array}$ & $n$ \\
\hline POAG & $\begin{array}{l}526.30 \pm 37.34 \\
445-615 \\
(516.86-535.73)\end{array}$ & 60 & $\begin{array}{l}524.90 \pm 35.92 \\
444-604 \\
(515.81-533.98)\end{array}$ & 60 \\
\hline OHT & $\begin{array}{l}547.32 \pm 35.71 \\
463-639 \\
(536.23-558.36)\end{array}$ & 40 & $\begin{array}{l}546.67 \pm 36.85 \\
47 I-649 \\
(535.19-558.00)\end{array}$ & 40 \\
\hline$P$ & 0.0130 & & 0.0073 & \\
\hline
\end{tabular}


Table 4 Linear regression of central corneal thickness

\begin{tabular}{|c|c|c|c|c|c|c|c|c|}
\hline \multirow[t]{2}{*}{ Variables } & Coefficient & $\begin{array}{l}\text { Standard } \\
\text { error }\end{array}$ & F-test & \multirow[t]{2}{*}{$P$ value } & \multirow{2}{*}{$\begin{array}{l}\text { Coefficient } \\
\text { Left }\end{array}$} & \multirow{2}{*}{$\begin{array}{l}\text { Standard } \\
\text { error } \\
\text { Eye }\end{array}$} & \multirow[t]{2}{*}{ F-test } & \multirow[t]{2}{*}{$P$ value } \\
\hline & Right & eye & & & & & & \\
\hline Age & 0.005 & 0.316 & 0.0002 & 0.9877 & -0.164 & 0.311 & 0.2769 & 0.5999 \\
\hline Group & 20.498 & 7.813 & 6.8837 & 0.01013 & 19.826 & 7.683 & 6.6582 & 0.0114 \\
\hline \multicolumn{9}{|l|}{ OHT/POAG } \\
\hline $\begin{array}{l}\text { Sex } \\
\text { (male/female) }\end{array}$ & 17.035 & 7.274 & 5.4772 & 0.02135 & 17.532 & 7.158 & 5.9985 & 0.01615 \\
\hline Constant & 517.227 & 19.098 & 733.455I & 0.0000 & 525.001 & 18.783 & 781.2869 & 0.0000 \\
\hline
\end{tabular}

Abbreviations: OHT, ocular hypertension; POAG, primary open angle glaucoma.

respective mean ages. This difference in CCT according to gender was also found by Mercieca et $\mathrm{a}^{15}$ (a study of black African subjects, Nigeria). On the contrary, Bron et $\mathrm{al}^{2}$ (Caucasians, France), Fanny et a ${ }^{18}$ (black African subjects, Ivory Coast) and Omgbwa et $\mathrm{al}^{19}$ in Cameroon found no statistically significant gender difference.

\section{According to age}

Although numerous studies have shown a decrease of CCT related to age, ${ }^{15,19,20}$ there was no statistically significant difference of CCT due to age within each group (POAG and OHT) in our study.

\section{According to group (POAG or OHT)}

Mean CCT of POAG group subjects $(n=60)$ is comparable to that found by Mercieca et al (CCT in Nigerian glaucomatous subjects: $527.36 \mathrm{~mm}) .{ }^{15}$ However, our results, although slightly higher than those found by Fanny et a $1^{18}$ (CCT in glaucomatous Ivory Coast subjects: $519.6 \pm 32.6 \mu \mathrm{m}$ ) do not differ significantly ( $P=0.1102$, 2-sample independent $t$ test). Our results are also close to those of Rosa et al ${ }^{12}$ (CCT of African American subjects: right, $529.5 \pm 9.6 \mu \mathrm{m}$ and left, $526.5 \pm 36 \mathrm{~mm}$ ). On the contrary, average CCT of Caucasian glaucomatous populations is greater than that found in black populations (Bron et al ${ }^{2}: 536 \pm 34 \mu \mathrm{m}[\mathrm{n}=63]$, La Rosa et al ${ }^{12}$ : $558.7 \pm 30.2 \mu \mathrm{m}$ in the right eye and $558.6 \pm 30.3 \mu \mathrm{m}$ in the left eye [n=13], Singh et $\left.\mathrm{al}^{21}: 547 \pm 34 \mu \mathrm{m}[\mathrm{n}=13]\right)$. In addition, mean CCT of the POAG group is similar to that of Omgbwa et al, ${ }^{19}$ based on the study of a Cameroonian nonglaucomatous population $(528.74 \pm 35.89 \mu \mathrm{m}, \mathrm{n}=970$ eyes, $P=0.73$, 2-sample independent $t$ test).

Average CCT of OHT group subjects $(\mathrm{n}=40)$, although thicker, is less than that found by Herman et $\mathrm{al}^{3}$ $(594 \pm 37 \mu \mathrm{m})$ and Bron et $\mathrm{al}^{2}(592 \pm 39 \mu \mathrm{m})$ in Caucasian populations. Therefore, the mean CCT of black Africans and African Americans is thinner than that of Caucasian subjects regardless of whether the subject is glaucomatous or not (Table 6). Although individuals within a group may exhibit variations in CCT (Figure 2), average CCT of the OHT group was significantly thicker than that of the POAG group. On this point, our results are similar to those of other authors (Meideros et al, ${ }^{6}$ Kniestedt et al, ${ }^{13}$ and Singh et $\mathrm{al}^{21}{ }^{21}$. Thus, these results suggest that $\mathrm{CCT}$, regardless of race, is thicker in the ocular hypertensive subject than in the POAG subject. In addition many studies ${ }^{2,6,20}$ show that CCT of a glaucomatous subject is comparable to that of a healthy subject regardless of race. This may explain the concordance between the average CCT of the POAG group and that of the sample of Cameroonian healthy subjects studied by Omgbwa et al. ${ }^{19}$ Based on the fact that Goldmann applanation tonometer is calibrated for corneas of $520 \mu \mathrm{m}$, and taking into account the reference values of the thickness of the cornea between 527 and $560 \mu \mathrm{m},{ }^{25}$ the IOP of $70 \%$ of glaucomatous subjects and of $60 \%$ of ocular hypertensive subjects would have needed a correction factor related to the thickness of their corneas (overestimation of IOP in

Table 5 Central corneal thickness (CCT) according to age and groups (POAG, OHT)

\begin{tabular}{|c|c|c|c|c|}
\hline \multirow[t]{2}{*}{ Age } & \multicolumn{2}{|l|}{ Glaucoma } & \multicolumn{2}{|c|}{ Ocular hypertension } \\
\hline & Right CCT & Left CCT & Right CCT & Left CCT \\
\hline$<50$ years & $538.28 \pm 44.29(14)$ & $538.28 \pm 41.750(14)$ & $547 \pm 38.23(18)$ & $546.61 \pm 41.85(18)$ \\
\hline $50-59$ years & $519.22 \pm 36.13(27)$ & $520.48 \pm 34.39(27)$ & $545.64 \pm 29.36(17)$ & $544.1 I \pm 28.63(17)$ \\
\hline 60 years and more & $527.52 \pm 32.83(19)$ & $521.31 \pm 32.86(19)$ & $554.20 \pm 52.03(5)$ & $555.60 \pm 48.88(5)$ \\
\hline$P($ ANOVA $)$ & 0.3011 & 0.2986 & 0.8986 & 0.8360 \\
\hline
\end{tabular}

Abbreviations: OHT, ocular hypertension; POAG, primary open angle glaucoma. 


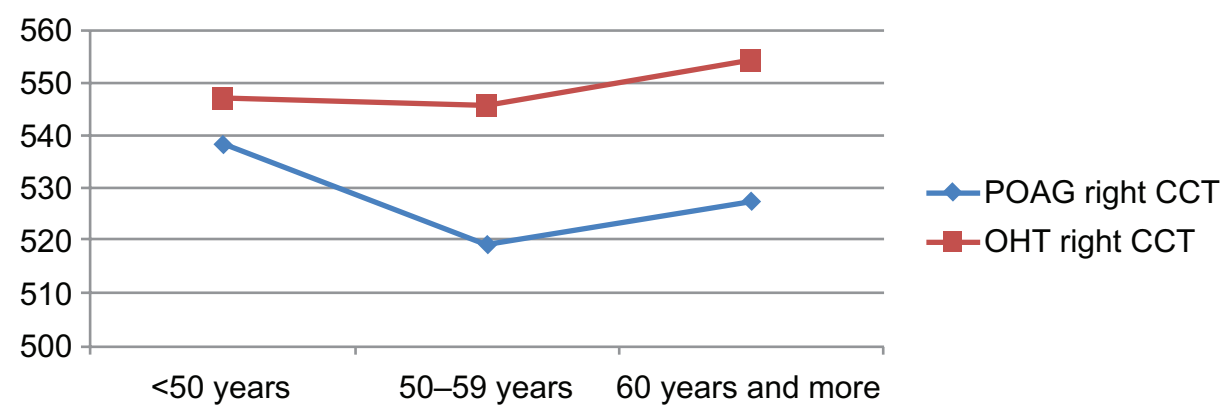

Figure I Right eye CCT according to age and groups.

Abbreviations: OHT, ocular hypertension; POAG, primary open angle glaucoma; CCT, central corneal thickness.

case of thick corneas and underestimation in case of thin corneas). Thus, in Cameroonian subjects, the measurement of CCT should be included in the routine eye examination for OHT. Even though there is a consensus on the impact of CCT on the IOP measured with a Goldmann applanation tonometer, there is still controversy about formulas for IOP adjustment. ${ }^{26-28}$ Therefore, IOP adjustment should be done by each ophthalmologist with the help of a wide spread algorithm of his choice.

\section{Limitations of the study}

The weaknesses of our study may be related to the size of our sample, although some authors studied smaller samples. Moreover, bias may be related to the use of a device in our study different from that used by other authors.

\section{Conclusion}

This study suggests that CCT in ocular hypertensive subjects is thicker than that of glaucomatous ones in the black Cameroonian population. Because CCT varies among individuals, it appears to be an important parameter in any OHT detected mainly in black subjects in whom the early onset and severity of glaucoma has been demonstrated. Thus, CCT can help to diagnose a true, elevated IOP in any patient with suspected open-angle glaucoma, be used in follow-up of a glaucomatous subject, or to diagnose an ocular hypertensive case. CCT should therefore be widely used in daily practice. Even though the impact of CCT on IOP is proven, there is no universal consensus on the formula to be used for IOP adjustment. Therefore, the IOP adjustment formula remains the choice of each ophthalmologist. For the future,

Table 6 Comparison of central corneal thickness (CCT) through different studies

\begin{tabular}{|c|c|c|c|c|c|c|}
\hline \multirow[t]{2}{*}{ Authors } & \multicolumn{3}{|l|}{ Glaucomatous } & \multicolumn{3}{|c|}{ Ocular hypertensives } \\
\hline & Black Africans & Black Americans & Caucasians & Black Africans & Black Americans & Caucasians \\
\hline \multirow[t]{2}{*}{ Our study } & $\begin{array}{l}R: 526.30 \pm 37.34 \\
(n=60 \text { subjects })\end{array}$ & & & $\begin{array}{l}R: 547.32 \pm 35.71 \\
(n=40 \text { subjects) }\end{array}$ & & \\
\hline & $\begin{array}{l}\mathrm{L}: 524.90 \pm 35.92 \\
(\mathrm{n}=60 \text { subjects })\end{array}$ & & & $\begin{array}{l}\mathrm{L}: 546.67 \pm 36.85 \\
(\mathrm{n}=40 \text { subjects) }\end{array}$ & & \\
\hline Fanny et $a^{18}$ & $\begin{array}{l}\text { R: } 519.6 \pm 32.6 \\
\text { ( } n=170 \text { subjects) } \\
L: 519.8 \pm 32.7 \\
\text { ( } n=170 \text { subjects) }\end{array}$ & & & & & \\
\hline Mercieca et $\mathrm{al}^{15}$ & $\begin{array}{l}526 \pm 38 \\
(n=36 \text { subjects })\end{array}$ & & & & & \\
\hline La Rosa et al ${ }^{12}$ & & $\begin{array}{l}R: 529.5 \pm 9.6 \\
(n=29 \text { subjects) } \\
L: 526.5 \pm 36 \\
\text { ( } n=29 \text { subjects) }\end{array}$ & $\begin{array}{l}R: 558.7 \pm 30.2 \\
(n=13 \text { subjects) } \\
L: 558.6 \pm 30.3 \\
(n=13 \text { subjects) }\end{array}$ & & & \\
\hline Singh et $\mathrm{al}^{21}$ & & & $\begin{array}{l}547 \pm 34 \\
(n=13 \text { subjects })\end{array}$ & & & $\begin{array}{l}570 \pm 32 \\
(n=4 I \text { subjects })\end{array}$ \\
\hline Bron et $\mathrm{al}^{2}$ & & & $\begin{array}{l}536 \pm 34 \\
(n=63 \text { eyes })\end{array}$ & & & $\begin{array}{l}592 \pm 39 \\
(n=48 \text { eyes })\end{array}$ \\
\hline
\end{tabular}




\section{CCT right eye}

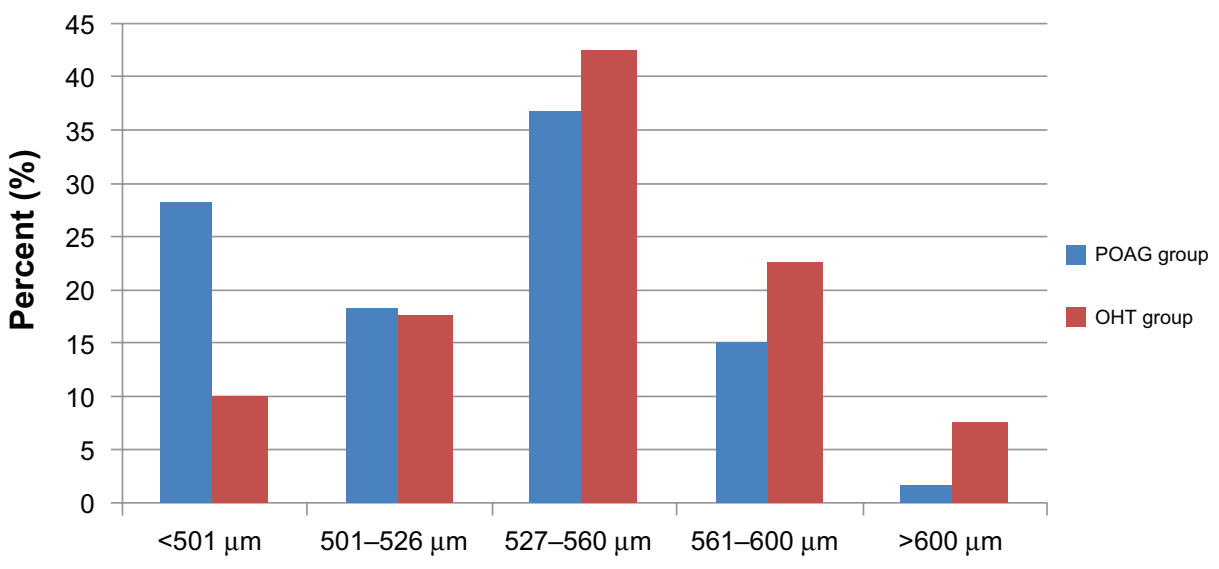

CCT left eye

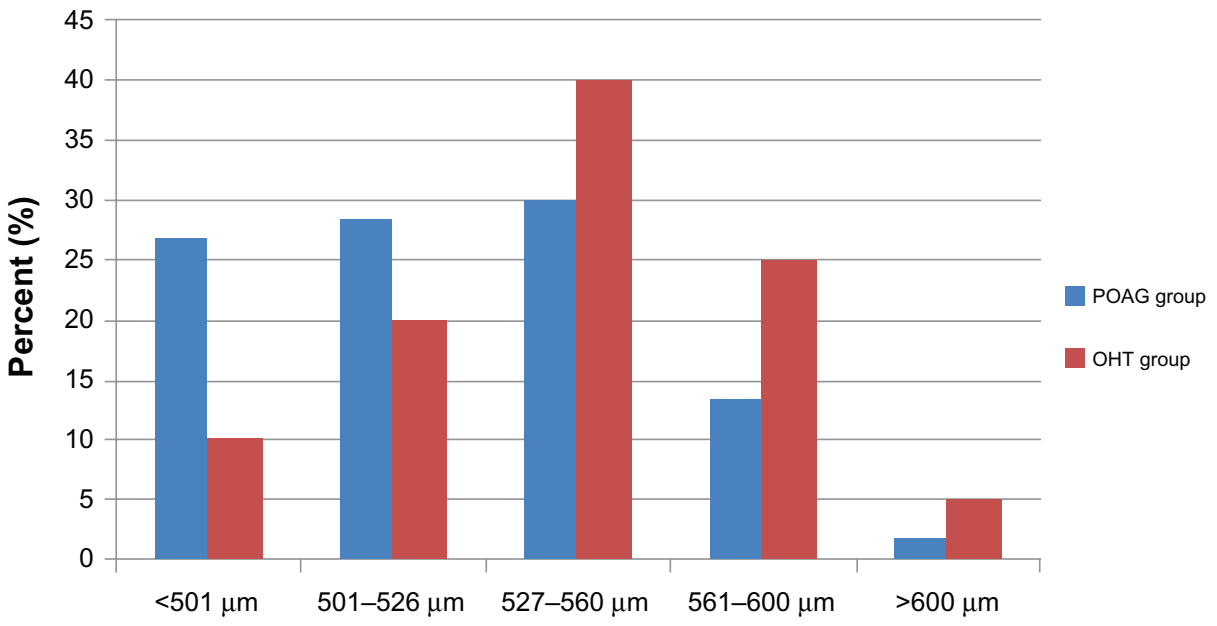

Figure 2 Distribution of the population according to the central corneal thickness (CCT).

Abbreviations: OHT, ocular hypertension; POAG, primary open angle glaucoma; CCT, central corneal thickness.

the tendency should be toward the use of tonometers less influenced by CCT.

\section{Disclosure}

The authors declare no conflicts of interest in this paper.

\section{References}

1. Weinreb RN, Khaw PT. Primary open-angle glaucoma. Lancet. 2004; 363:1711-1720.

2. Bron AM, Creuzot-Garcher C, Goudeau-Boutillon S, d'Athis P. Falsely elevated intraocular pressure due to increased central corneal thickness. Graefes Arch Clin Exp Ophthalmol. 1999;237:220-224.

3. Herman DC, Hodge DO, Bourne WM. Increased corneal thickness in patients with ocular hypertension. Arch Ophthalmol. 2001;119: 334-336.

4. Brandt JD, Beiser JA, Kass MA, et al. Central corneal thickness in the ocular Hypertension Hypertension Study (OHTS). Ophthalmology. 2001;108:1779-1788.

5. Gordon MO, Beiser JA, Brandt JD, et al. The ocular hypertension treatment study: baseline factors that predict the onset of primary open-angle glaucoma. Arch Ophthalmol. 2002;120:714-720.
6. Meideros FA, Sample PA, Weinreb RN. Corneal thickness measurements and visual function abnormalities in ocular hypertensive patients. Am J Ophthalmol. 2003;135:131-137.

7. Detry-Morel M. Use of corneal pachymetry in ocular hypertension and chronic glaucoma. Bull Soc Belge Ophtalmol. 2004;293:35-43.

8. Böhm AG. The risk of glaucoma and corneal thickness. Ophthalmology. 2005;102:909-916.

9. von Eicken J, Kohlhaas M, Stodtmeister R, Höh H. The role of pachymetry in routine glaucoma diagnosis. Klin Monbi Augenheilkd. 2006;223:117-130.

10. Dueker DK, Singh K, Lin SC, et al. Corneal thickness measurement in the management of primary open-angle glaucoma: a report by the American Academy of Ophthalmology. Ophthalmology. 2007;114: 1779-1789.

11. Lester M, Mete M, Figus M, Frezzotti P. Incorporing corneal pachymetry into the management of glaucoma. J Cataract Refract Surg. 2009; 35:1623-1628.

12. La Rosa FA, Gross RL, Orengo-Nania S. Central corneal thickness of Caucasians and African Americans in glaucomatous and nonglaucomatous populations. Arc Ophthalmol. 2001;119:23-27.

13. Kniestedt C, Lin S, Choe J, Nee M, Bostrom A, Stürmer J, Stamper RL. Correlation between intraocular pressure, central corneal thickness, stage of glaucoma, and demographic patient data: prospective analysis of biophysical parameters in tertiary glaucoma practice populations. J Glaucom. 2006;15:91-97. 
14. Semes L, Shaikh A, McGwin G, Bartlett JD. The relationship among race, iris color, central corneal thickness, and intraocular pressure. Optom Vis Sci. 2006;83:512-515.

15. Mercieca K, Odogu V, Fiebai B, Arowolo O, Chukwuka F. Comparing central corneal thickness in a sub-saharan cohort to African Americans and afro-carribeans. Cornea. 2007;26:557-560.

16. Torres RJ, Jones E, Edmunds B, Becker T, Cioffi GA, Mansberger SL. Central corneal thickness in Northwestern American Indians/Alaskan Natives and comparison with White and African-American persons. Am J Ophthalmol. 2008;146:747-751.

17. Fansi AA, Papamatheakis DG, Harasymowycz PJ. Racial variability of glaucoma risk factors between African Carribbeans and Caucasians in a Canadian urban screening population. Can J Ophthalmol. 2009;44:576-581.

18. Fanny A, Ouattara A, Coulibaly F, et al. Central corneal thickness and potential error in Goldmann applanation tonometry of the Black African patient suffering from primary open-angle glaucoma. J Fr Ophtalmol. 2008;31:405-408.

19. Omgbwa EA, Koki G, Ellong A, et al. Central corneal thickness and intraocular pressure in the Cameroonian nonglaucomatous population. Clin Ophthalmol. 2010;4:717-724.

20. Iyamu E, Ituah I. The relationship between central corneal thickness and intraocular pressure: a comparative study of normals and glaucoma subjects. Afr J Med Sci. 2008;37:345-353.
21. Singh RP, Goldberg I, Graham SL, Sharma A, Mohsin M. Central corneal thickness, tonometry, and ocular dimensions in glaucoma and ocular hypertension. J Glaucoma. 2001;10:206-210.

22. Tuck MW, Crick RP. The age distribution of primary open angle glaucoma. Ophthalmic Epidemiol. 1998;5:173-183.

23. de Voogd S, Ikram MK, Wolfs RC, Jansonius NM, Hofman A, de Jong PT Incidence of open-angle glaucoma in a general elderly population: The Rotterdam Study. Ophthalmology. 2005;112:1487-1493.

24. Leske MC, Connell AM, Wu SY, Hyman LG, Schachat AP. Risk factors for open-angle glaucoma. The Bardabos Eye Study. Arch Ophthalmol. 1995;113:918-924.

25. Detry-Morel M. Utilité de la pachymétrie cornéenne dans l'hypertension oculaire et le glaucome chronique. Bull Soc Belge Ophthalmol. 2004; 293:1-9.

26. Brandt JD. Corneal thickness in glaucoma screening, diagnosis, and management. Current Opin Ophthalmol. 2004;15:85-89.

27. Hagerb A, Dave H, Wiegand W. Corneal pachymetry and intraocular pressure. Klin Monbl Augerheilkd. 2005;222:558-567.

28. Hemdon LW. Measuring intraocular pressure- adjustments for corneal thickness and new technologies. Curr Opin Ophthalmol. 2006;17 $115-119$.
Clinical Ophthalmology

\section{Publish your work in this journal}

Clinical Ophthalmology is an international, peer-reviewed journal covering all subspecialties within ophthalmology. Key topics include: Optometry; Visual science; Pharmacology and drug therapy in eye diseases; Basic Sciences; Primary and Secondary eye care; Patien Safety and Quality of Care Improvements. This journal is indexed on

Submit your manuscript here: http://www.dovepress.com/clinical-ophthalmology-journal

\section{Dovepress}

PubMed Central and CAS, and is the official journal of The Society of Clinical Ophthalmology (SCO). The manuscript management system is completely online and includes a very quick and fair peer-review system, which is all easy to use. Visit http://www.dovepress.com/ testimonials.php to read real quotes from published authors. 